\title{
Penerapan Metode Weighted Product dalam Pengambilan Keputusan Penerimaan Asisten Laboratorium Komputer dengan Metode Weighted Product
}

\author{
Randa Hendro Nurman ${ }^{1)}$, Ahmadi ${ }^{2)}$ \\ ${ }^{1}$ Prodi Sistem Informasi STMIK Bina Nusantara Jaya Lubuklinggau \\ ${ }^{2}$ Prodi Manajemen Informatika STMIK Bina Nusantara Jaya Lubuklinggau \\ Jl. Yos Sudarso No. 97 A Kel. Jawa Kanan Kota Lubuklinggau Sumatera Selatan \\ Telp : (0733) 322306 \\ E-mail : randadarkangel@gmail.com ${ }^{1)}, \underline{\text { ahmadi.bnj@gmail.com }}^{2)}$
}

\begin{abstract}
The existence of assistants in the computer laboratory is an important element in supporting the process of implementing practicum learning. A laboratory assistant who is assigned to assist teachers in practicum activities must understand practicum material and be able to guide students to achieve predetermined competency standards. The process of admitting computer laboratory assistants has several assessment criteria, both academic and non-academic. Errors in decision making cause distrust of the quality of computer laboratory assistants received and have an impact on reducing students' understanding and skills in certain subjects. With the construction of the "Decision Support System for Computer Laboratory Assistant Admissions with the Weighted Product Method at SMK N 5 Rejang Lebong", it can help teachers to be more selective in placing students who do have competence in the IT field at the computer laboratory of SMK N 5 Put Rejang Lebong which was previously every Once a year, it is only chosen not based on an assessment of the student's academic score which leads to a particular ability
\end{abstract}

Keywords: Decision, Laboratory Assistant, School, PHP, MySQL

\begin{abstract}
Abstrak
Keberadaan asisten di laboratorium komputer merupakan salah satu unsur penting dalam menunjang proses pelaksanaan pembelajaran praktikum. Seorang asisten laboratorium yang bertugas sebagai pendamping guru pada kegiatan praktikum harus memahami materi praktikum dan mampu membimbing siswa untuk mencapai standar kompetensi yang telah ditetapkan. Proses penerimaan asisten laboratorium komputer memiliki beberapa kriteria penilaian baik dari akademik maupun non akademik. Kesalahan dalam pengambilan keputusan menimbulkan ketidak percayaan terhadap kualitas asisten laboratorium komputer yang diterima dan berdampak pada menurunnya pemahaman dan keterampilan siswa terhadap mata pelajaran tertentu. Dengan dibangunnya "Sistem Pendukung Keputusan Penerimaan Asisten Laboratorium Komputer Dengan Metode Weighted Product Pada SMK N 5 Rejang Lebong" dapat membantu guru untuk lebih selektif dalam penempatan siswa yang memang memiliki kompetensi dalam bidang IT pada laboratorium komputer SMK N 5 Put Rejang Lebong yang sebelum nya setiap 1 tahun sekali hanya dipilih bukan berdasarkan penilaian dari nilai akademik siswa yang mengarah pada kemampuan tertentu.
\end{abstract}

Kata kunci : Keputusan, Asisten Laboratorium, Sekolah, PHP, MySQL

\section{Pendahuluan}

Sistem Pendukung Keputusan atau SPK sendiri memiliki beberapa metode salah satu diantaranya Metode Weighted Product (WP) merupakan suatu metode pengambilan keputusan yang efisien dalam perhitungan, selain itu waktu yang dibutuhkan lebih singkat dan banyak digunakan untuk menyelesaikan permasalahan dengan menggunakan perkalian antara nilai kriteria yang telah ditentukan, yang di mana nilai dari setiap kriteria harus dipangkatkan terlebih dahulu dengan bobot kriteria yang telah ditetapkan di awal [1].

Keberadaan asisten di laboratorium komputer merupakan salah satu unsur penting dalam menunjang proses pelaksanaan pembelajaran praktikum. Seorang asisten laboratorium yang bertugas sebagai pendamping guru pada kegiatan praktikum harus memahami materi praktikum dan mampu membimbing siswa untuk mencapai standar kompetensi yang telah ditetapkan. Proses penerimaan asisten laboratorium komputer memiliki beberapa kriteria penilaian baik dari akademik maupun non akademik. Kesalahan dalam pengambilan keputusan menimbulkan ketidak percayaan terhadap kualitas asisten laboratorium komputer yang diterima dan berdampak pada menurunnya pemahaman dan keterampilan siswa terhadap mata pelajaran tertentu.

Pada laboratorium komputer SMK Negeri 05 Rejang Lebong kepala laboratorium komputer menetapkan beberapa siswanya sebagai asisten laboratorium dalam satu tahun sekali atau setiap dua semester, asisten 
laboratorium yang mendapat tanggung jawab sebagai Asisten Laboratorium (Aslab) selama satu tahun akan diganti ketika asisten laboratorium sudah menyelesaikan pendidikannya pada saat mereka lulus, proses perekrutan asisten laboratorium hanya dipilih berdasarkan pengamatan non akademik dari kepala laboratorium dan tidak menggunakan data akademik yang dimiliki oleh setiap siswa. Proses penyeleksian calon asisten laboratorium ini hanya berdasarkan pengamatan kepala laboratorium komputer terhadap penilaian sikap dan atas kemauan dari siswa yang berminat, jika siswa dinilai memiliki sikap yang cukup baik maka kepala laboratorium akan menjadikan hal tersebut salah satu point penilaian dalam menentukan kriteria calon asisten laboratorium.

\section{Tinjauan Pustaka}

\subsection{Sistem Pendukung Keputusan (SPK)}

SPK (sistem pendukung keputusan) adalah sistem yang dibangun untuk menyelesaikan berbagai masalah yang bersifat manajerial atau organisasi perusahaan yan dirancang untuk mengembangkan efektivitas dan produktivitas para manajer untuk menyelesaikan masalah dengan bantuan teknologi komputer [2]

Sistem Pendukung Keputusan (Decision Suport System) adalah sistem berbasis komputer yang interaktif dalam membantu pengambil keputusan dengan memanfaatkan data dan model untuk menyelesaikan masalah-masalah yang terstruktur [3]

\subsection{Asisten Laboratorium}

\section{Asisten laboratorium komputer merupakan salah satu 3.1 Metode Pengumpulan Data}

unsur penting dalam menunjang proses pelaksanaan Untuk mendapatkan data yang sesuai dengan pembelajaran praktikum. Seorang asisten laboratorium permasalahan yang dibutuhkan tersebut dibutuhkan yang bertugas sebagai pendamping guru pada kegiatan teknik pengumpulan data. Teknik pengumpulan data praktikum harus memahami materi praktikum dan yang digunakan dalam penelitian ini adalah interview mampu membimbing siswa untuk mencapai standar (wawancara), Study Litelatur.

kompetensi yang telah ditetapkan [4]

\subsection{Weighted Product (WP)}

Weighted Product (WP) adalah salah satu metode prototyping karena selain menghemat waktu metode ini penentuan urutan atau prioritas dalam MCDM (Multi memiliki kelebihan dalam komunikasi yang baik antara Criterion Decesin Making) atau menentukan dan pengembang dan pelanggan, sehingga pengembang menghasilkan pendukung keputusan dari beberapa dapat bekerja lebih baik dalam menentukan kebutuhan alternative. [5]

Adapun langkah penyelesaian dalam menggunakannya pengembangan system yang diharapkannya. Model adalah:

Prototyping dimulai dari mengumpulkan kebutuhan

1. Perbaikan bobot kriteria, dengan persamaan sebagai pelanggan terhadap perangkat lunak yang akan dibuat berikut:

$$
W_{j}=\frac{W_{j}}{\sum W_{j}}
$$

Lalu dibuatlah program Prototyping agar pelanggan

2. Menghitung vektor $\mathrm{S}$. langkah ini sama seperti proses normalisasi, dengan persamaan sebagai berikut:

$$
S_{i}=\prod \prod_{j=1}^{n} X_{i j_{w j}} i=1,2, \ldots m
$$

tampak seperti perangkat lunak yang sudah jadi.

(2) Program Prototyping ini dievaluasi oleh pelanggan atau 
user sampai ditemukan spesifikasi yang sesuai dengan 4.2 Perancangan DFD keinginan pelanggan atau user

\section{Hasil dan Pembahasan}

\subsection{Analisis Sistem}

Dalam membangun sebuah sistem yang sudah terkomputerisasi berupa sistem pendukung keputusan penerimaan asisten laboratorium komputer dengan menggunakan metode Weighted Product. Metode Weighted Product merupakan metode pengambilan keputusan multi kriteria yang dapat melakukan perhitungan untuk memilih asisten laboratorium yang tepat sesuai dengan kriteria akademik dan non akademik yang diinginkan keplab sehingga pemilihan asisten laboratorium tidak dilakukan hanya berdasarkan dari kriteria non akademik saja.

Dengan menggunakan sistem maka pemilihan asisten laboratorium dapat dilakukan dengan mudah dan cepat sehingga membantu bagian keplab meningkatkan mutu kualitas siswa yang menjadi asisten laboratorium nantinya. Penggunaan sistem pendukung keputusan ini diharapkan mampu menghindari terjadinya kesalahan dalam proses pemilihan dan mampu menghasilkan informasi yang tepat dan akurat. Selain itu dengan tersedianya fasilitas database maka data penilaian calon asisten laboratorium dapat disimpan secara terorganisir untuk digunakan kembali sewaktu-waktu dibutuhkan.

Adapun gambaran dari sistem pendukung keputusan pemilihan asisten laboratorium komputer yang ditawarkan dapat dilihat pada gambar 1 dibawah ini

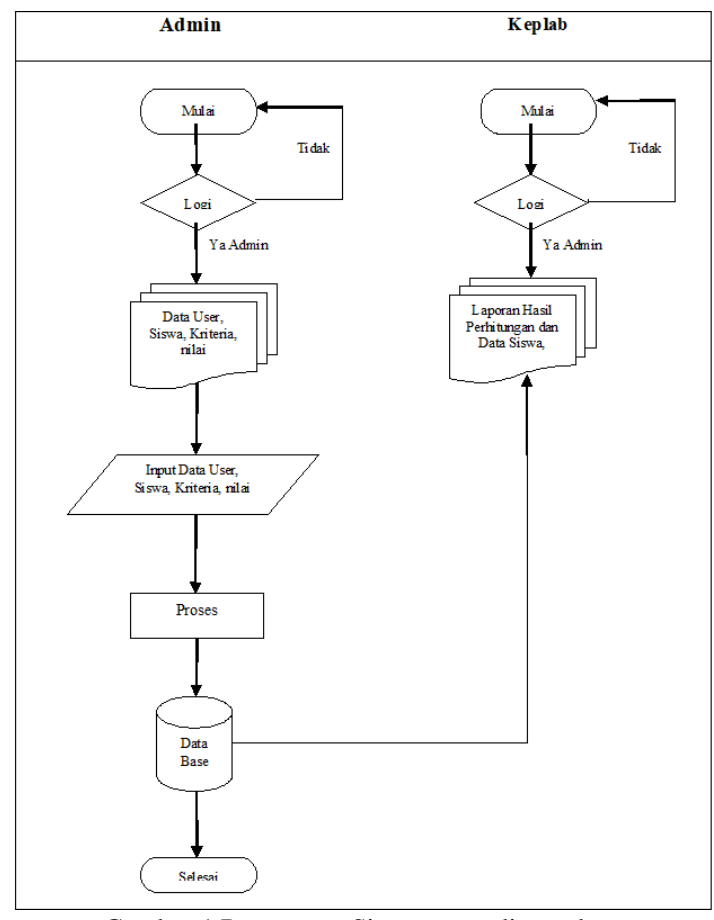

Gambar 1 Rancangan Sistem yang ditawarkan

\section{DFD Level 0}

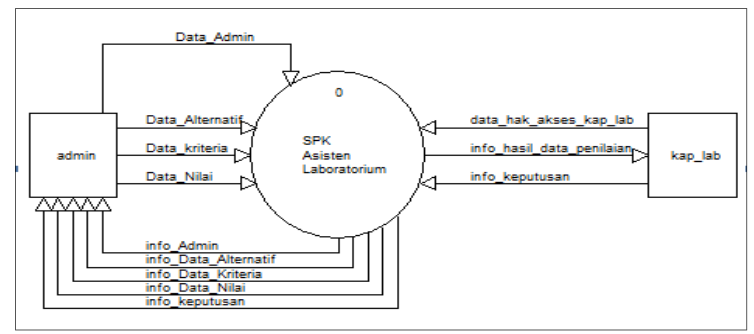

Gambar 2 DFD Level 0

2. DFD Level 1

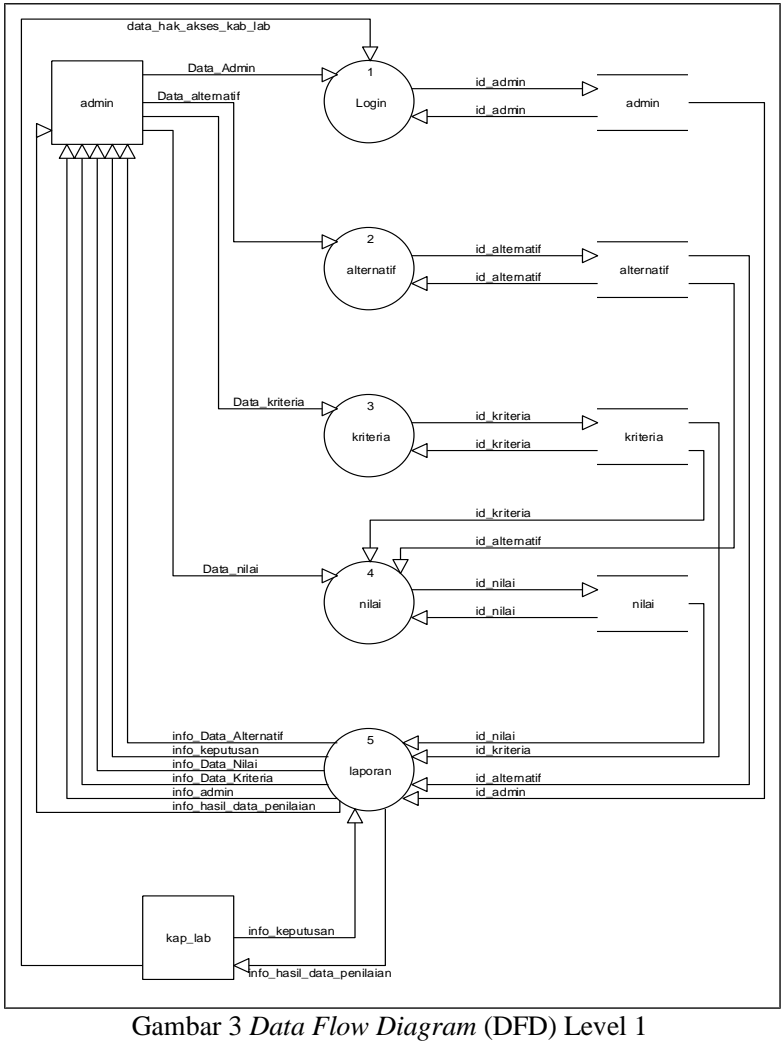

Pada Data Flow Diagram diatas dapat dilihat saat admin akan mengelola data, admin harus melakukan login terlebih dahulu. Setelah login berhasil maka akan tampil halaman utama dan admin bisa mengelola data melalui menu yang telah tersedia dan dapat dilihat beberapa proses aliran data yang terjadi pada sistem yang akan dibuat, proses-proses tersebut antara lain adalah:

1. Pendataan Admin

ada proses pendataan admin digunakan untuk mendata siapa saja yang berhak masuk kedalam aplikasi ini, sehingga pihak-pihak yang tidak terdaftar dalam pendataan admin tidak dapat mengakses aplikasi ini.

2. Pendataan alternatif

Proses pendataan alternatif merupakan proses dimana alternatif yang masuk dalam kategori calon penerimaan asisten laboratorium Komputer (ASLAB) di

Jurnal Ilmiah Binary STMIK Bina Nusantara Jaya

Vol. 02 No. 02 Tahun 2020, ISSN : 2657-2117 
data untuk kemudian data tersebut akan digunakan Dengan ketentuan bobot yang telah didapat dari hasil dalam proses perhitungan untuk mengetahui siapa yang wawancara kepada kepala laboratorium ditentukan nanti akan menjadi asisten laboratorium.

$\mathrm{C}_{1}=3, \mathrm{C}_{2}=3, \mathrm{C}_{3}=2, \mathrm{C}_{4}=1, \mathrm{C}_{5}=1$.

3. Pendataan Kriteria

Sistem dapat melakukan pengolahan data kriteria yang akan digunakan dalam proses perhitungan untuk menentukan siswa yang layak diterima.

4. Pendataan Penilaian/keputusan

Sistem dapat melakukan pengolahan data nilai yang akan digunakan dalam proses perhitungan untuk menentukan siswa yang layak diterima.

5. Laporan

3. Pendataan nilai alternatif

implementasi perhitungan metode Weighted

Product, pada SMK Negeri. 05 Rejang Lebong dalam melakukan pemilihan asisten laboratorium komputer dengan jumlah kandidat 10 siswa.

\section{a) Data Alternatif}

Data alternatif yang dibutuhkan dan akan diproses Pada menu ini admin dapat mencetak dan memberikan kompetensi masing-masing alternatif adalah data siswa laporan kepada kepala sekolah terkait hasil perhitungan yang ditunjukan pada tabel berikut :

dan data lainnya yang diperlukan.

\section{Perancangan ERD}

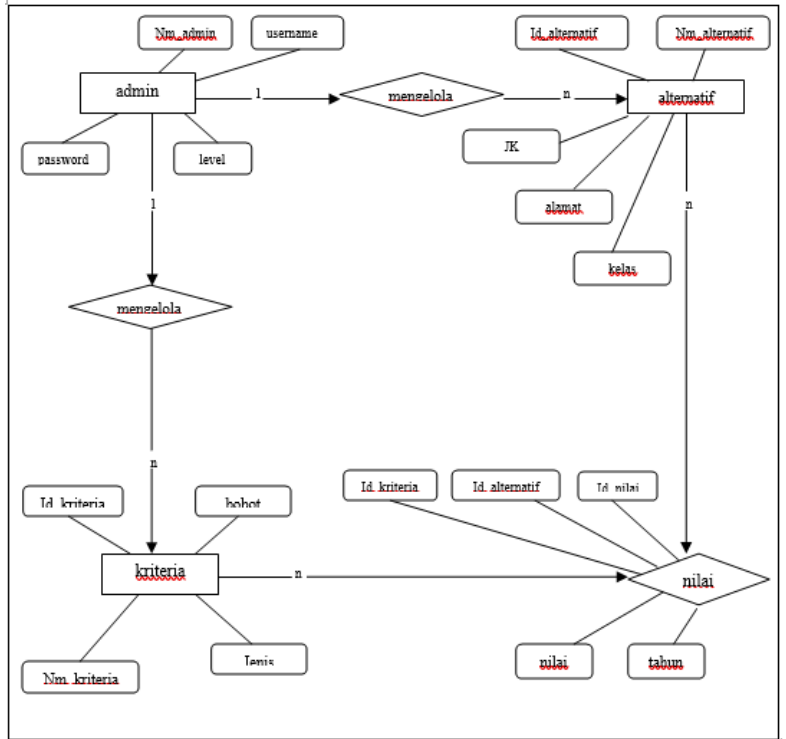

Gambar 4. Entity Relationship diagram (ERD)

4.4 Pembahasan/Perhitungan

Adapun bahan yang akan digunakan dalam melakukan proses perhitungan diantaranya :

1. Kriteria

Kriteria pemilihan asisten laboratorium yang telah direkomendasikan adalah Instalasi Jaringan, Instalasi Sistem Operasi, Bahasa Inggris, Sikap/Disiplin dan Kemauan/Minat

\section{Pembobotan}

Dalam metode penelitian ini ada nilai bobot setiap kriteria yang dibutuhkan untuk menentukan pemilihan pada SMK N. 05 Rejang Lebong, Adapun kriterianya adalah $\left(\mathrm{C}_{1}=\right.$ Instalasi Jaringan, $\mathrm{C}_{2}=$ Instalasi Sistem Operasi, $\mathrm{C}_{3}=$ Bahasa Inggris, $\mathrm{C}_{4}=$ Sikap/Disiplin, dan $\mathrm{C}_{5}=$ Kemauan $/$ Minat $)$

Adapun tingkat kepentingan yang nantinya akan dibobotkan untuk setiap kriteria adalah (3 = Sangat Penting, 2= Cukup Penting, dan 1= Penting

\begin{tabular}{clll}
\hline Kd & Nama Alternatif & JK & Kelas \\
\hline A1 & Andi & L & 2(TKJ) \\
A2 & Antoni & L & $2($ TKJ) \\
A3 & Ayu & P & $2($ TKJ) \\
A4 & Azi & L & $2($ TKJ) \\
A5 & Azmi & P & $2($ TKJ) \\
A6 & Dahlia & P & $2($ TKJ) \\
A7 & Fajri & L & $2($ TKJ) \\
A8 & Keke & P & 2(TKJ) \\
A9 & Purwantoro & L & 2(TKJ) \\
A10 & Suhardi & L & 2(TKJ) \\
\hline \multicolumn{5}{c}{ Tabel 5 Daftar Nama Siswa }
\end{tabular}

Dari hasil pendataan data nilai alternatif yang dilakukan dengan menyebarkan formulir data nilai ke siswa yang kemudian dilakukan pendataan maka hasil data alternatif dapat dilihat pada table 6 berikut :

Tabel 6 Nilai kriteria dari masing-masing alternatif

\begin{tabular}{llccccc}
\multirow{2}{*}{ Kd } & \multicolumn{1}{c}{$\begin{array}{c}\text { Nama } \\
\text { Alternatif }\end{array}$} & C1 & C2 & C3 & C4 & C5 \\
\hline A1 & Andi & 87 & 80 & 70 & $5 \%$ & 100 \\
& Wiratama & & & & & \\
A2 & Antoni & 85 & 78 & 80 & $70 \%$ & 100 \\
A3 & Ayu & 75 & 85 & 75 & $64 \%$ & 100 \\
A4 & Azi & 80 & 75 & 80 & $78 \%$ & 100 \\
A5 & Azmi & 73 & 75 & 60 & $63 \%$ & 100 \\
A6 & Dahlia & 87 & 85 & 70 & $75 \%$ & 100 \\
A7 & Fajri & 85 & 78 & 67 & $77 \%$ & 100 \\
A8 & Keke & 78 & 70 & 85 & $75 \%$ & 100 \\
A9 & Purwantoro & 87 & 73 & 78 & $75 \%$ & 100 \\
A10 & Suhardi & 89 & 80 & 70 & $65 \%$ & 100 \\
& & & & & &
\end{tabular}

b. Menentukan Rating Kecocokan

Menentukan rating kecocokan data alternatif dan kriteria yang diperoleh, kemudian kriteria dan alternatif tersebut dicocokkan dan akan memperoleh rating kecocokan dapat dilihat pada table 7 dibawah ini. 
Tabel 7 Nilai Alternatif Setiap Kriteria

\begin{tabular}{llrrrrr}
\hline \multirow{2}{*}{ Kd } & Nama & \multicolumn{5}{c}{ Nilai } \\
\cline { 2 - 6 } & Alternatif & C1 & C2 & C3 & C4 & C5 \\
\hline A1 & Andi & 87 & 80 & 70 & $75 \%$ & 100 \\
& Wiratama & & & & & \\
A2 & Antoni & 85 & 78 & 80 & $70 \%$ & 100 \\
A3 & Ayu & 75 & 85 & 75 & $64 \%$ & 100 \\
A4 & Azi & 80 & 75 & 80 & $78 \%$ & 100 \\
A5 & Azmi & 73 & 75 & 60 & $63 \%$ & 100 \\
A6 & Dahlia & 87 & 85 & 70 & $75 \%$ & 100 \\
A7 & Fajri & 85 & 78 & 67 & $77 \%$ & 100 \\
A8 & Keke & 78 & 70 & 85 & $75 \%$ & 100 \\
A9 & Purwantoro & 87 & 73 & 78 & $75 \%$ & 100 \\
A10 & Suhardi & 89 & 80 & 70 & $65 \%$ & 100 \\
\hline
\end{tabular}

Langkah selanjutnya menentukan normalisasi bobot (nilai) dari setiap kriteria, dimana bobot (nilai) ditentukan oleh pengambil keputusan berdasarkan tingkat kepentingan yang disimbolkan dengan (W). Bobot (nilai) yang diberikan yaitu nilai terbesar adalah 3 = menjadi nilai yang sangat penting, 2 = cukup penting, 1 = penting, seperti terlihat pada tabel 8 sebagai berikut:

\begin{tabular}{cclr}
\multicolumn{3}{c}{ Tabel 8 Bobot (Nilai) Kriteria } \\
\hline No & Kriteria & \multicolumn{1}{c}{ Keterangan } & $\begin{array}{r}\text { Bobot } \\
\text { (Nilai) }\end{array}$ \\
\hline 1 & C1 & $\begin{array}{l}\text { Instalasi } \\
\text { Jaringan }\end{array}$ \\
2 & C2 & $\begin{array}{l}\text { Instalasi Sistem } \\
\text { Operasi }\end{array}$ & 3 \\
3 & C3 & Bahasa Inggris & 2 \\
4 & C4 & Sikap/Disiplin & 1 \\
5 & C5 & Kemauan/Minat & 1 \\
\hline
\end{tabular}

4. Proses Weighted Product (WP)

Setelah tabel 3.4 dibuat bobot ( Nilai ) Kriteria maka langkah selanjutnya melakukan perhitungan bobot kriteria Sebelumnya dilakukan perbaikan bobot terlebih dahulu sehingga $\Sigma \mathrm{W}=1$,

1. Menghitung Bobot Kriteria

Menghitung total bobot kemudian dibagi bobot masing-masing kriteria seperti di bawah ini.

$$
\begin{aligned}
& \text { C1 } \frac{3}{1+1+3+3+2}=3 / 10=0,3 \\
& \text { C2 } \frac{3}{1+1+3+3+2}=3 / 10=0,3 \\
& \text { C3 } \frac{2}{1+1+3+3+2}=2 / 10=0,2 \\
& \text { C4 } \frac{1}{1+1+3+3+2}=1 / 10=0,1 \\
& \text { C5 } \frac{1}{1+1+3+3+2}=1 / 10=0,1
\end{aligned}
$$

2 Menghitung Nilai Vektor $S$ Untuk menghitung nilai Vektor $S$ adalah nilai di pangkatkan dengan total bobot untuk masingmasing nilai kriteria.
$\mathrm{S}_{1}=\left(87^{0,3}\right)\left(80^{0,3}\right)\left(70^{0,2}\right)\left(75^{0,1}\right)\left(100^{0,1}\right)=$ 81.1537338299

$\mathrm{S}_{2}=\left(85^{0,3}\right)\left(78^{0,3}\right)\left(80^{0,2}\right)\left(70^{0,1}\right)\left(100^{0,1}\right)=$ 81.579654167

$\mathrm{S}_{3}=\left(75^{0,3}\right)\left(85^{0,3}\right)\left(75^{0,2}\right)\left(64^{0,1}\right)\left(100^{0,1}\right)=$ 78.8813449435

$\mathrm{S}_{4}=\left(80^{0,3}\right)\left(75^{0,3}\right)\left(80^{0,2}\right)\left(78^{0,1}\right)\left(100^{0,1}\right)=$ 80.0336885306

$\mathrm{S}_{5}=\left(73^{0,3}\right)\left(75^{0,3}\right)\left(60^{0,2}\right)\left(63^{0,1}\right)\left(100^{0,1}\right)=$ 71.9580758877

$\mathrm{S}_{6}=\left(87^{0,3}\right)\left(85^{0,3}\right)\left(70^{0,2}\right)\left(75^{0,1}\right)\left(100^{0,1}\right)=$ 82.643211956

$\mathrm{S}_{7}=\left(85^{0,3}\right)\left(78^{0,3}\right)\left(67^{0,2}\right)\left(77^{0,1}\right)\left(100^{0,1}\right)=$ 79.4910239993

$\mathrm{S}_{8}=\left(78^{0,3}\right)\left(70^{0,3}\right)\left(85^{0,2}\right)\left(75^{0,1}\right)\left(100^{0,1}\right)=$ 78.441827716

$\mathrm{S}_{9}=\left(87^{0,3}\right)\left(73^{0,3}\right)\left(78^{0,2}\right)\left(75^{0,1}\right)\left(100^{0,1}\right)=$ 80.6821905035

$\mathrm{S}_{10}=\left(89^{0,3}\right)\left(80^{0,3}\right)\left(70^{0,2}\right)\left(65^{, 1}\right)\left(100^{0,1}\right)=$ 80.5480334519

3. Menghitung Nilai Vektor V

Menghitung Vektor V dengan melakukan pembagian Vektor S dibagi dengan total nilai Vektor S

$\mathrm{V} 1=\frac{81.1537338299}{795.412784986}=0.10202719312$

$\mathrm{V} 2=\frac{81.579654167}{795.412784986}=0.10256266394$

$V 3=\frac{78.8813449435}{795.412784986}=0.09917032568$

$V 4=\frac{80.0336885306}{795.412784986}=0.10061906225$

$\mathrm{V} 5=\frac{71.9580758877}{795.412784986}=0.09046633049$

$V 6=\frac{82.6432119565}{795.412784986}=0.10389977822$

$\mathrm{V} 7=\frac{79.4910239993}{795.412784986}=0.09993681959$

V8 $=\frac{78.441827716}{795.412784986}=0.09861776073$

$\mathrm{V} 9=\frac{80.6821905035}{795.412784986}=0.10143436468$

$\mathrm{V} 10=\frac{80.5480334519}{795.412784986}=0.10126570124$ 
4. Melakukan Perangkingan Nilai Vektor V

Setelah mendapatkan nilai Vektor V maka langkah selanjutnya mengurutkan nilai Vektor $\mathrm{V}$ dari urutan terbesar ke urutan terkecil seperti pada tabel 9 sebagai berikut.

\begin{tabular}{lll}
\multicolumn{3}{c}{ Tabel 9 Hasil Perangkingan } \\
\hline No & Nama Alternatif & Nilai \\
\hline $\mathbf{1}$ & Dahlia & 0.10389977822 \\
\hline $\mathbf{2}$ & Antoni & 0.10256266394 \\
\hline $\mathbf{3}$ & Andi Wiratama & 0.10202719312 \\
\hline $\mathbf{4}$ & Purwantoro & 0.10143436468 \\
\hline $\mathbf{5}$ & Suhardi & 0.10126570124 \\
\hline $\mathbf{6}$ & Azi & 0.10061906225 \\
\hline $\mathbf{7}$ & Fajri & 0.09993681959 \\
\hline $\mathbf{8}$ & Ayu & 0.09917032568 \\
\hline $\mathbf{9}$ & Keke & 0.09861776073 \\
\hline $\mathbf{1 0}$ & Azmi & 0.09044633049 \\
\hline
\end{tabular}

5. Keputusan Alternatif Terbaik

Dari hasil perangkingan pada tabel 3.5 di atas dapat diambil sebuah keputusan bahwa alternatif tiga kandidat terbaik adalah Dahlia dengan nilai 0.10389977822 diikuti Antoni dengan nilai 0.10256266394 dan Andi Wiratama dengan nilai 0.10202719312

\subsection{Implementasi}

\section{Login Sistem}

Pada halaman login ini digunakan untuk admin dan kepala laboratorium. Serta terdapat tombol login untuk masuk kedalam sistem dengan cara menginputkan username dan password. Jika username dan password yang di inputkan benar maka akan menampilkan halaman utama sesuai hak akses masing-masing. Halaman login dapat dilihat pada gambar berikut:

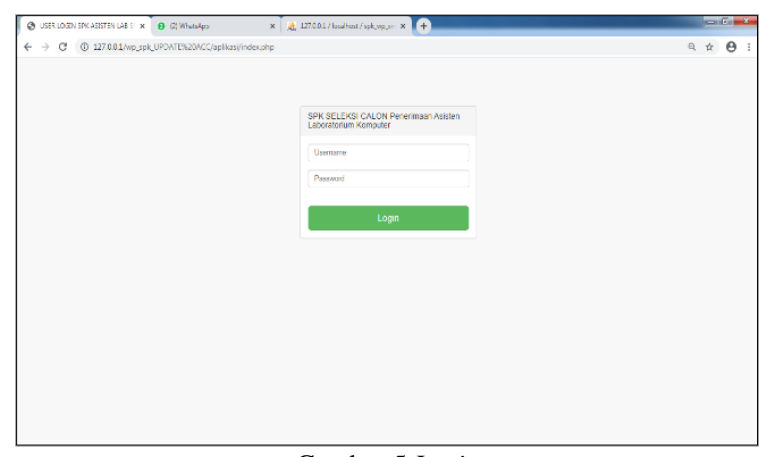

Gambar 5 Login

2. Input Data Nilai

Pada halaman input data nilai yang akan digunakan 5.2 Saran

untuk memberikan nilai perengkingan pada SPK ini kedepan kiranya dapat dikembangkan kembali kandidat asisten laboratorium.. Halaman input data sesuai kebutuhan nilai dapat dilihat pada gambar 6 berikut:

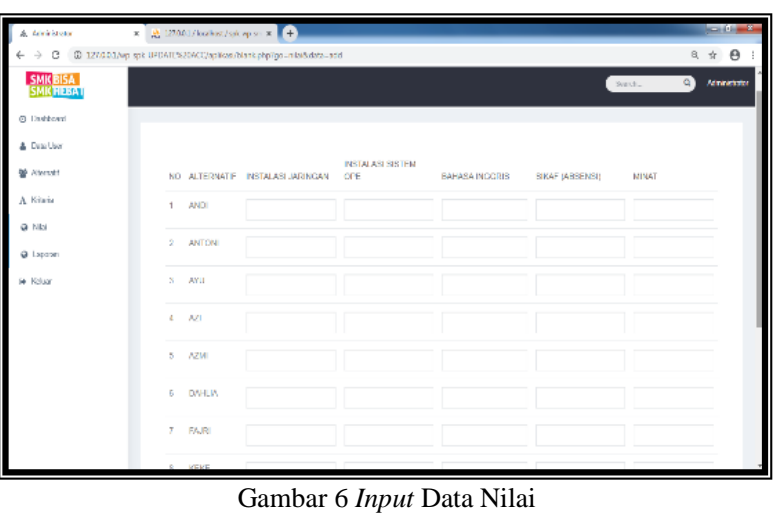

3. Hasil Perangkingan

Pada halaman ini akan menampilkan hasil dari perengkingan data-data alternatif, kriteria dan nilai akhir pada masing-masing data. Halaman tampilan hasil perengkingan dapat dilihat pada gambar 7 berikut :

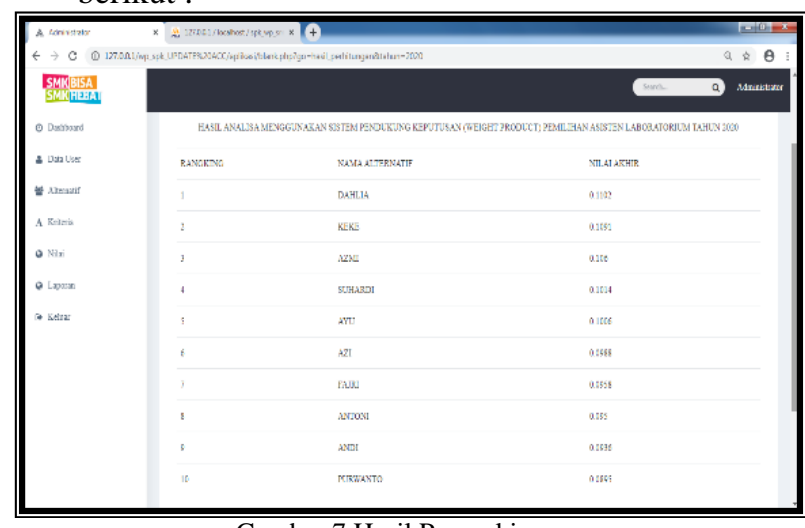

\section{Kesimpulan}

Dari hasil penelitian yang telah dilakukan maka dihasilkan .

\subsection{Simpulan}

Sistem pendukung keputusan yang dibangun dapat memperkuat keputusan yang akan diambil oleh kepala laboratorium komputer pada SMK N.05 Rejang Lebong dalam menerima atau menempatkan calon asisten laboratorium sesuai dengan kemampuan yang dimiliki siswa sehingga lebih tepat sasaran dengan memanfaatkan teknologi informasi.

Sistem pendukung keputusan penerimaan asisten laboratorium komputer dapat mempermudah proses perhitungan atau perengkingan nilai siswa yang akan dijadikan syarat untuk menjadi asisten laboratorium komputer. 


\section{Daftar Rujukan}

[1] Hafis A, Ikhsan F K, Sulasminarti, Widiyastuti A dan Ma'Mur, 2017, Penerapan metode Weighted Product pada Sistem Pendukung Keputusan ISSN : 23674421.

[2] Armiyana , Reski Mai Candra, 2017. Sistem Pendukung Keputusan Pemilihan Sekolah Anak Dengan Menggunakan Metode Analytical Hierarchy Process (AHP) Dan Metode Perbandingan Eksponensial (MPE), vol.3, no.1, hal. 31-34.

[3] Pratiwi 2016, Sistem Pendukung Keputusan (Decision Suport System) ISSN : 2655-3421.

[4] Tati Mardiana., 2018, SPK Penerimaan Asisten Laboratorium Komputer Menggunakan Metode Method AHP-TOPSIS ISSN : 2527-4864.

[5] Joko Andrianto, 2017, SPK Pemilihan Jurusan Dengan Metode Weighted Product untuk SiswaSiswi SMA Negeri 1 SALE ISSN : 2365-3421. 